\title{
Supramolecular Nanostructure Activates TrkB Receptor Signaling of Neuronal Cells by Mimicking Brain-Derived Neurotrophic Factor
}

\author{
Alexandra N. Edelbrock ${ }^{\# 1,2}$, Zaida Àlvarez $\# 2$, Dina Simkin ${ }^{3,4}$, Timmy Fyrner², Stacey M. \\ Chin $^{5}$, Kohei Sato ${ }^{2,5, \ddagger}$, Evangelos Kiskinis ${ }^{4}$, and Samuel I. Stupp ${ }^{1,2,5,6,7, \#}$ \\ ${ }^{1}$ Department of Biomedical Engineering, Northwestern University, Evanston, Illinois 60208, USA; \\ 2Simpson Querrey Institute, Northwestern University, Chicago, Illinois 60611, USA; \\ ${ }^{3}$ Department of Pharmacology, Feinberg School of Medicine, Northwestern University, Chicago, \\ IL, 60611, USA; \\ ${ }^{4}$ The Ken \& Ruth Davee Department of Neurology, Department of Physiology, Feinberg School of \\ Medicine, Northwestern University, Chicago, IL 60611, USA; \\ ${ }^{5}$ Department of Chemistry, Northwestern University, Evanston, Illinois 60208, USA; \\ ${ }^{6}$ Department of Materials Science and Engineering, Northwestern University, Evanston, Illinois \\ 60208, USA \\ ${ }^{7}$ Department of Medicine, Northwestern University, Chicago, IL 60611, USA. \\ \# These authors contributed equally to this work.
}

\begin{abstract}
Brain-derived neurotrophic factor (BDNF), a neurotrophin which binds specifically to the tyrosine kinase B (TrkB) receptor, has been shown to promote neuronal differentiation, maturation, and synaptic plasticity in the central nervous system (CNS) during development or after injury and onset of disease. Unfortunately, native BDNF protein-based therapies have had little clinical success due to their suboptimal pharmacological properties. In the past 20 years, BDNF mimetic peptides have been designed with the purpose of activating certain cell pathways that mimic the functional activity of native BDNF, but the interaction of mimetic peptides with cells can be limited due to the conformational specificity required for receptor activation. We report here on the incorporation of a BDNF mimetic sequence into a supramolecular peptide amphiphile filamentous
\end{abstract}

\footnotetext{
\#Corresponding Author: Samuel I. Stupp, s-stupp@northwestern.edu.

†Present address: Department of Life Science and Technology, Tokyo Institute of Technology, Yokohama 226-8501, Japan Author Contributions

A.N.E. and Z.A. contributed equally to this work. A.N.E. synthesized materials, A.N.E. and Z.A. designed and performed experiments, analyzed data, and wrote the manuscript. D.S. performed all electrophysiology experiments and analyzed data. S.M.C. performed analysis experiments and analyzed data. T.F. and K.S. carried out synthetic work, material characterization, and took part in discussions. E.K. supervised the research. S.I.S. wrote the manuscript and supervised the research. The manuscript was written through contributions of all authors. All authors have given approval to the final version of the manuscript.

Supporting Information. Supporting information includes additional figures, description of synthetic procedures, and a detailed explanation of materials and methods used. The following files are available free of charge. Supporting Information (PDF)

The authors declare no competing financial interest.
} 
nanostructure capable of activating the BDNF receptor TrkB and downstream signaling in primary cortical neurons in vitro. Interestingly, we found that this BDNF mimetic peptide is only active when displayed on a peptide amphiphile supramolecular nanostructure. We confirmed that increased neuronal maturation is linked to TrkB signaling pathways by analyzing the phosphorylation of downstream signaling effectors and tracking electrical activity over time. Furthermore, three-dimensional gels containing the BDNF peptide amphiphile (PA) nanostructures encourage cell infiltration while increasing functional maturation. Our findings suggest that the BDNF mimetic PA nanostructure creates a highly bioactive matrix that could serve as a biomaterial therapy in injured regions of the CNS. This new strategy has the potential to induce endogenous cell infiltration and promote functional neuronal maturation through the presentation of the BDNF mimetic signal.

\section{Graphical Abstract}

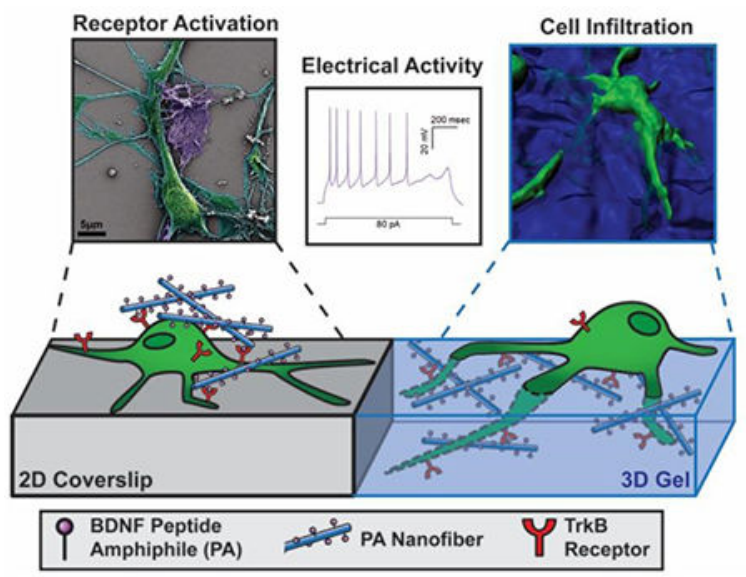

\section{Keywords}

BDNF Mimetic; Neurons; Peptide Amphiphile; Nanostructure; TrkB Receptor; Maturation

The ability of neurotrophic factors to regulate the developing central nervous system (CNS) and to promote survival has motivated the use of these proteins to treat CNS injuries and diseases. ${ }^{-}$The main neurotrophins include brain-derived neurotrophic factor (BDNF), nerve growth factor, neurotrophin-3, and neurotrophin-4.- Among these, BDNF is the most extensively studied due to its key role during development and its capacity to mediate neuroprotection and functional recovery post-injury. It is well known that BDNF binds with high affinity to the tyrosine kinase B (TrkB) receptor and with low affinity to $\mathrm{p} 75^{\mathrm{NTR}}$, a nonspecific neurotrophin receptor.' ' Additionally, BDNF activates certain cell pathways promoting neuronal survival, differentiation, maturation, re-myelination, and synaptic plasticity. ${ }^{-}$Previous studies have shown that decreased BDNF levels interfere with the healing process after injury in the CNS and also affect neurodegenerative conditions including Parkinson's and Alzheimer's diseases.' These findings indicate the potential therapeutic role for BDNF in neural regeneration.' Unfortunately, BDNF-based therapies have had little clinical success, ${ }^{-}$and this has motivated the search for alternative therapies to enhance BDNF receptor signaling. A common problem with the majority of protein 
therapies is their short half-life, and synthetic nanostructures have been shown to circumvent this problem.'

Several BDNF mimetic peptide sequences were identified by Hughes et al. that promoted the survival of neuronal cultures.' In their work, a computer-aided molecular design approach was used to identify these BDNF mimetic peptides. The most recently reported peptide was cyclic arginine-lysine-lysine-alanine-D-proline (RKKADP) found in loop 4 of the native BDNF protein, which was the only monocyclic mimetic found to behave as a BDNF-like agonist.' They found that this sequence increased survival of chick sensory neurons and improved re-myelination in a peripheral nerve injury via TrkB-independent mechanisms. Despite their mimetic design, Hughes et al. found that the RKKADP peptide in this monocyclic conformation did not activate the TrkB receptor and therefore does not truly mimic the native growth factor.'

Self-assembling supramolecular systems have been identified as an important class of biomaterials given their ability to generate ordered and dynamic structures. Peptide amphiphiles (PAs) that self-assemble in water into high aspect ratio nanofibers and form hydrogel networks in the presence of physiological electrolytes have emerged as attractive supramolecular candidates for regenerative medicine.' PAs have been shown to be highly bioactive and mimic natural extracellular matrices. ${ }^{-}$We previously developed PAs displaying diverse bioactive epitopes such as IKVAV, FGF-2, and VEGF with the ability to activate $\beta-1$ integrin, FGFR-1, and VEGFR-1 receptors, respectively. We report here on the incorporation of the RKKADP BDNF mimetic peptide on a PA capable of assembling in aqueous media into one-dimensional supramolecular nanostructures. The objective of this work has been to investigate the ability of supramolecular nanostructures created with a PA containing a BDNF mimetic peptide (BDNF PA) to activate the TrkB receptor. In previous work, the BDNF mimetic peptide (BDNF Peptide) alone was not able to activate the receptor.' The activation of the TrkB receptor and its corresponding pathways were characterized by studying intracellular signaling of primary cortical neurons treated with BDNF PA. We also investigated the survival, growth, and functional maturation of these cells in 2D and 3D cultures.

\section{Design and Characterization of the BDNF Mimetic Peptide Amphiphile Nanostructure.}

The bioactive portion of the BDNF peptide consists of three amino acids (arginine-lysinelysine) cyclized using a D-Proline to ensure the correct steric conformation for receptor binding (Figure 1a). The BDNF peptide developed by the Hughes lab also contained a nonbioactive alanine which they replaced with a lysine without significant biological effects. For the design of the BDNF PA, we used this lysine to link the BDNF peptide to a hexa-ethylene glycol $\left(\mathrm{PEG}_{6}\right)$ spacer to increase the distance of the BDNF sequence from the PA nanofiber surface and ensure signal bioavailability (Figure 1b). The PA molecular backbone was designed with four glutamic acid residues followed sequentially by two alanine residues, two valine residues $\left(\mathrm{V}_{2} \mathrm{~A}_{2} \mathrm{E}_{4}\right)$, and an alkyl tail of 16 carbons $\left(\mathrm{C}_{16}\right)$. The four glutamic acids ensured solubility of the PA molecule, while $\mathrm{V}_{2} \mathrm{~A}_{2}$ and $\mathrm{C}_{16}$ created the nanostructure via $\beta$ - 
sheet formation and hydrophobic collapse, respectively. A PA containing a non-cyclized BDNF peptide (Linear BDNF PA) was synthesized as a control to probe the specificity of peptide conformation on receptor binding (Figure 1c, for synthetic procedure see SI section 1.4). The non-bioactive backbone, $\mathrm{C}_{16} \mathrm{~V}_{2} \mathrm{~A}_{2} \mathrm{E}_{2} \mathrm{PA}\left(\mathrm{E}_{2} \mathrm{PA}\right.$ ) (Figure 1d), was used for both BDNF PA nanostructures because of its known ability to form robust nanoribbons on its own.

Cryogenic transmission electron microscopy (Cryo-TEM) demonstrated that the BDNF PA and the Linear BDNF PA alone (100 mol\%) were unable to form nanofibers, likely due to the large steric demands of the BDNF structure (Figure 1e and S1). Dynamic light scattering (DLS) confirmed that the BDNF PA forms spherical micelles with a diameter distribution centered at $12 \mathrm{~nm}$ (Figure 1f). For optimal fiber formation, we investigated different coassembly ratios $(10,20,50,70$ and $90 \mathrm{~mol} \%)$ of the BDNF PA with $\mathrm{E}_{2}$ (Figure 1g-i, S1). We also found that $\mathrm{C}_{16} \mathrm{~V}_{2} \mathrm{~A}_{2} \mathrm{E}_{4}\left(\mathrm{E}_{4} \mathrm{PA}\right.$ ) or $\mathrm{C}_{16} \mathrm{~V}_{2} \mathrm{~A}_{2} \mathrm{E}_{4} \mathrm{PEG}_{6}\left(\mathrm{E}_{4} \mathrm{PEG} \mathrm{PA}\right)$, which are present in the full sequence of the BDNF PA, were unable to form nanofibers at $100 \mathrm{~mol} \%$. We observed that as the molar ratio of BDNF PA to $\mathrm{E}_{2} \mathrm{PA}$ increased, the propensity to form fibrous nanostructures decreased significantly (Figure S1). To corroborate these findings, the co-assemblies in solution were analyzed by small angle x-ray scattering (SAXS) which, for the $E_{2} P A$, yielded a slope of -2 in the Guinier region fit to a lamellar model (Figure $1 \mathrm{j}$ and S2). BDNF PA co-assemblies (10-70 mol\%) exhibited a slope of -1 , indicating cylindrical nanofibers and fit a cylindrical core shell model (Figure S2b). Conversely, $100 \mathrm{~mol} \%$ BDNF PA solutions exhibited a slope of 0 in the Guinier region corresponding to spherical nanostructures (Figure $1 \mathrm{j}$ and $\mathrm{S} 2 \mathrm{~b}$ ), which is consistent with the DLS data (Figure 1f). In order to assess the formation of hydrogen bonding among PA molecules within the nanofiber, we carried out measurements of circular dichroism (CD) and Fourier-transform infrared (FT-IR) spectroscopy. CD and FT-IR spectra of PA materials except for the $\mathrm{E}_{2}$ PA, revealed a random coil secondary signature by the lack of positive ellipticity in the $\mathrm{CD}$ spectrum (Figure S3a, c) and a broad amide I band around $1640-1650 \mathrm{~cm}^{-1}$ in FT-IR spectra (Figure S3e). All PA compositions that were co-assembled at $10 \mathrm{~mol} \%$ with $\mathrm{E}_{2}$ PA revealed a $\beta$-sheet signature in CD spectra and a peak between $1610-1625 \mathrm{~cm}^{-1}$ in their FI-TR spectra (Figure S3b, d, f).

\section{Cellular Response to the BDNF Mimetic Peptide Amphiphile Nanostructures.}

We evaluated the ability of the BDNF PA supramolecular nanostructure to mimic the BDNF protein by analyzing its effect on embryonic primary mouse cortical neurons in vitro. For these experiments we used $1 \mathrm{wt} \%$ solutions obtained by co-assembling $10 \mathrm{~mol} \%$ of the BDNF PA, Linear BDNF PA, or $\mathrm{E}_{4} \mathrm{PEG}$ PA with $90 \mathrm{~mol} \% \mathrm{E}_{2}$ PA. These solutions were annealed at $80{ }^{\circ} \mathrm{C}$ for 30 minutes and slow cooled to reach the thermodynamically favored fiber formation (See SI section 2.1.1 for more information). These co-assemblies are referred to as BDNF PA, Linear BDNF PA or $\mathrm{E}_{2}+\mathrm{E}_{4} \mathrm{PEG}$ PA, respectively. PAs were then added to media to treat the cells for in vitro studies. Scanning electron microscopy (SEM) and fluorescent confocal microscopy confirmed that the PA fibers in media interacted with neural cells (Figure 2a and S4a-c). 
To determine the ability of the BDNF PA to activate the TrkB receptor,', we investigated the receptor phosphorylation kinetics using western blot analysis at different time points. The BDNF PA was added to the media (containing $0.5 \mu \mathrm{M}$ of PA molecules with the BDNF mimetic sequence) for 2, 4, 6, 8, 12, and 24h and compared to the addition of BDNF protein at an initial dose of $0.25 \mathrm{nM}(8 \mathrm{ng} / \mathrm{mL})$, at the same timepoints (Figure $2 \mathrm{~b}, \mathrm{c})$. As expected, neuronal cells treated with BDNF protein showed an initial peak in phosphorylated TrkB (pTrkB) between 2 and $4 \mathrm{~h}$ which then began to decrease gradually, and activation was no longer observed after $12 \mathrm{~h}$. On the other hand, cells treated with BDNF PA showed a peak in p-TrkB between 4 and $6 \mathrm{~h}$, indicating their ability to activate the receptor. We also observed that the BDNF PA and BDNF protein induced similar levels of p-TrkB $6 \mathrm{~h}$ after they were added to the media (Figure 2c). To exclude the possibility of any cytotoxic effect of the PAs, a cell viability assay was performed on primary cortical neurons for 1,3, and 7-day timepoints (Figure S4d). The cell survival remained above $80 \%$ for all conditions, which is indicative of a healthy primary culture. To further verify receptor activation by BDNF PA, we pre-treated cortical neurons with the Trk selective pharmacological inhibitor K252a for $2 \mathrm{~h}$ prior to treatment with BDNF PA or BDNF protein (Figure S5). Western blot analysis showed that both BDNF PA and BDNF protein-induced TrkB phosphorylation was completely blocked by K252a $6 \mathrm{~h}$ post-treatment. The results suggest that the BDNF PA not only activates the TrkB receptor but does so through a similar mechanism as the BDNF protein.

To study the nature of the TrkB receptor activation by our PA, all components of the BDNF PA (BDNF Peptide, $\mathrm{E}_{2} \mathrm{PA}$, and $\mathrm{E}_{2}$ co-assembled with $\mathrm{E}_{4} \mathrm{PEG} \mathrm{PA}$ ), as well as the linear analogue of the BDNF PA, were studied in parallel. At 4 and $6 \mathrm{~h}$ timepoints, none of the components of the BDNF PA were found to induce TrkB phosphorylation (Figure 2d, e and S6). The lack of TrkB phosphorylation in the presence of the Linear BDNF PA indicates that the cyclic form of the BDNF mimetic sequence is critical to bind and activate the receptor. Consistent with previous observations, the BDNF cyclic peptide alone did not show activation of the TrkB receptor, suggesting that the activation in the presence of the BDNF peptide requires presentation by a PA supramolecular nanostructure. Neuronal cells treated with increasing concentrations of BDNF PA $(0.5,1.0$, and $5.0 \mu \mathrm{M})$ did not reveal dosedependent activation of TrkB (Figure S7). Since the $0.5 \mu \mathrm{M}$ dose was able to activate the total amount of TrkB receptors present in the experimental cells, this dose was used throughout our subsequent experiments. Furthermore, none of the control samples tested induced TrkB activation at higher concentrations $(1.0$ and $5 \mu \mathrm{M})$. These results indicate that molecular conformation of the cyclic BDNF mimetic sequence and its presentation on a supramolecular scaffold are required for cell signaling.

To further understand cell signaling by the BDNF PA nanostructure, we treated neuronal cells with different PA co-assembly ratios with $\mathrm{E}_{2} \mathrm{PA}(10,20,50$, and $90 \mathrm{~mol} \%)$ at a concentration of $0.5 \mu \mathrm{M}$ for $6 \mathrm{~h}$ (Figure S8). Within the range of 10-90 mol\% BDNF PA, we observed an activation of the TrkB receptor. Conversely, $100 \mathrm{~mol} \%$ of the BDNF mimetic PA, which does not self-assemble into nanoscale filaments, did not activate the receptor. To confirm that the BDNF peptide presentation on a PA supramolecular nanostructure plays a critical role in TrkB phosphorylation, we immobilized the BDNF peptide on a solid surface where we expect different molecular dynamics relative to soluble peptides. We also 
synthesized an additional BDNF peptide control functionalized with a $\mathrm{PEG}_{6}$ linker ( $\mathrm{PEG}_{6}-\mathrm{BDNF}$ peptide) in order to probe its role in bioactivity. This control was added since this particular linker is present in the BDNF PA, and it is well known that flexible PEG linkers or branched structures can increase the bioavailability of epitopes.- For this purpose, 3-aminopropyl triethoxysilane (APTES)-treated glass coverslips were functionalized with the BDNF or the $\mathrm{PEG}_{6}-\mathrm{BDNF}$ peptide using 1-ethyl-3-(dimethyl-

aminopropyl)carbodiimide (EDC) chemistry (Figure S9a, b and Synthetic Scheme SI section 1.6). On surfaces coated with the immobilized BDNF mimetic peptide and the immobilized $\mathrm{PEG}_{6}-\mathrm{BDNF}$ mimetic peptide, neuronal cell survival was reduced to $29 \%$ and $34 \%$, respectively (Figure S9c-e). Control surfaces coated with poly-D-lysine (PDL), which is widely used in the growth of primary neuronal cultures, showed $98 \%$ cell survival. Neural cells on APTES-treated control surfaces did not survive after 5 days in vitro (DIV). Due to the low amount of protein obtained from these studies, western blot analysis of TrkB receptor phosphorylation was not possible. As an alternative, we covalently attached the BDNF peptide or PEG $_{6}-\mathrm{BDNF}$ peptide to $6 \mu \mathrm{m}$ silica microspheres to treat neuronal cultures in solution (Figure S10a, b). Neuronal cells treated with BDNF peptide or $\mathrm{PEG}_{6}-\mathrm{BDNF}$ peptide functionalized silica microspheres did not show any activation of the TrkB receptor in primary neuronal cultures in vitro (Figure $\mathrm{S} 10 \mathrm{c}-\mathrm{e}$ ). These results indicate that the BDNF peptides attached covalently to the surface of the silica microspheres is not sufficient to activate the BDNF receptor. This also suggests that there are unique dynamic features for receptor activation provided by the one-dimensional peptide amphiphile supramolecular nanostructure.

\section{BDNF PA-TrkB Signaling Activates MAPK, PI3K and PLC $\gamma$.}

BDNF-TrkB signaling is involved in transcription, translation, and trafficking of proteins during various phases of synaptic development and has been implicated in several forms of synaptic plasticity.', These functions are carried out by a combination of three signaling cascades triggered when BDNF binds to TrkB: the mitogen-activated protein kinase (MAPK), the phosphatidylinositol 3-kinase (PI3K), and the phospholipase-C gamma (PLC $\gamma$ ) pathways. Activation of the MAPK and PI3K pathways was detected by western blot analysis using antibodies against phosphorylated ERK (pERK 1/2) and phosphorylated AKT (pAKT), respectively (Figure 2f, g). The BDNF PA and native BDNF protein showed a marked increase in activation of the MAPK and PI3K pathways in comparison with the control samples after $6 \mathrm{~h}$ of treatment. These pathways play crucial roles in dendrite formation, neuron survival, and axonal growth.' The PLC $\gamma$ pathway, which is one of the pathways associated with synaptic plasticity, , was highly activated for all samples (BDNF $\mathrm{PA}, \mathrm{BDNF}$ protein, $\mathrm{BDNF}$ peptide alone, $\mathrm{E}_{2}+\mathrm{E}_{4} \mathrm{PEG} \mathrm{PA}$, and starvation media) suggesting that this activation can also be associated to other stimuli in the cell culture environment. We conclude that the western blot analysis confirms the ability of the BDNF PA to induce the activation of MAPK and PI3K downstream pathways associated with the TrkB receptor that are important for survival, growth, and synaptic plasticity.' 


\section{Neural Plasticity and Maturation Mediated by the BDNF Peptide Amphiphile Nanostructure.}

Next, we investigated if activation of the receptor, and consequently downstream pathways, can be associated with changes in neuronal morphology. For this purpose, we cultured primary mouse cortical neurons with various treatments (BDNF peptide, $\mathrm{E}_{2}$ PA, BDNF PA, native BDNF protein as well as starvation media as a control) for 24 and $72 \mathrm{~h}$. The neuritic complexity was analyzed using immunocytochemistry with microtubule associated protein 2 (MAP-2) and pan-axonal neurofilament protein (SMI312), which are dendritic and axonal markers, respectively (Figure 3a and S11a). It has been shown previously that treatment with BDNF protein facilitates neurite branching, ${ }^{-}$so we sought to explore if the BDNF PA nanostructure could induce a similar effect. After $24 \mathrm{~h}$, cells treated with the BDNF PA showed a significant increase in the axon length $(208 \pm 36.2 \mu \mathrm{m})$ relative to the native BDNF protein $(116.4 \pm 7.5 \mu \mathrm{m})$ and all other control treatments (starvation media: $106.8 \pm 7.6 \mu \mathrm{m}$; BDNF peptide: $108.8 \pm 7.9 \mu \mathrm{m} ; \mathrm{E}_{2} \mathrm{PA}: 102.5 \pm 6.8 \mu \mathrm{m}$ ) (Figure $3 \mathrm{~b}$ ). In addition, the BDNF PA led to higher numbers of primary neurites $(5.08 \pm 1.52)$, (extensions coming directly from the soma), and a significant increase in the number of secondary neurites $(2.18 \pm 0.23)$ compared to neurons treated with starvation media (primary: $3.6 \pm 1.68$; secondary: 1.06 \pm 0.17 ), BDNF Peptide (primary: $4.6 \pm 1.2$; secondary: $1.15 \pm 0.2$ ), and $\mathrm{E}_{2} \mathrm{PA}$ (primary: 4.7 \pm 1.75 ; secondary: $1.2 \pm 0.2$ ). There were no statistical differences in neurite number between cells treated with the BDNF PA and native BDNF protein. After 72h in vitro, neurons exposed to these two treatments had similar axonal (BDNF PA: 517.6 $\pm 66.7 \mu \mathrm{m}$; BDNF protein: $426.2 \pm 25.7 \mu \mathrm{m}$ ) and dendritic length (BDNF PA: $519.7 \pm 78.03 \mu \mathrm{m}$, BDNF protein: $540 \pm 48.07 \mu \mathrm{m}$ ) compared to control samples (Figure S11b). We hypothesize that the increase in neurite development observed for cells treated with the BDNF PA at earlier time points can be attributed to the synergistic stimulus of topographical and biochemical cues provided by the PA supramolecular nanostructures. To assess the effect of the BDNF PA on neuronal maturation, the expression of mature neuronal markers was examined at long time points (Figure 3c). Neuronal cells were treated with the BDNF PA and native BDNF protein during 16 DIV and showed a significant increase of MAP-2, a marker associated with mature dendrites, relative to control treatments. Moreover, post-synaptic density 95 (PSD95), which plays an important role in post-synaptic plasticity, showed an increase for both of these treatments and as well as the BDNF peptide (Figure 3d, e). We conclude that TrkB activation by the BDNF PA nanostructure enhances neuronal maturation in vitro.

\section{Functional Analysis Through Electrophysiology.}

To determine if enhanced expression of neuronal maturation markers correlated with functional maturation, we assessed electrical activity of primary mouse cortical neurons. A multi-electrode array (MEA) platform was used to assess the spontaneous and synchronized activity of neuronal cultures over time, as illustrated in the spike raster plots on day 14 and day 30 from a well treated with BDNF PA (Figure 4a-c and S12). Cells cultured with the BDNF PA and BDNF protein for 30 DIV showed increased spontaneous firing frequency (BDNF PA: $5.9 \pm 0.5 \mathrm{~Hz}$; BDNF protein: $4.9 \pm 0.2 \mathrm{~Hz}$ ) relative to starvation media 
(starvation: $2.1 \pm 0.37 \mathrm{~Hz}$ ) (Figure 4d). Over time, cells treated with the BDNF PA or BDNF native protein were able to fire longer network bursts (BDNF PA: $3.1 \pm 0.24 \mathrm{sec}$; BDNF protein: $4.1 \pm 0.44 \mathrm{sec}$ ) with significantly more spikes per network burst (BDNF PA: 2947 \pm 333.2 ; BDNF protein: $2929 \pm 252.2$ ) than those in the control media (starvation media: $667.5 \pm 132.2$; BDNF peptide: $1714 \pm 251.6$ ) (Figure 4e, f). These results demonstrate that the treatment of neuronal cells with the BDNF PA can alter the developmental timeline of neuronal network excitability in primary neuronal cultures.

\section{Increased Maturation, Infiltration and Electrical Activity of Neurons on Three-Dimensional BDNF PA Scaffolds.}

Next, we investigated whether neurons could survive, infiltrate, and functionally mature to carry information by generating action potentials on three-dimensional (3D) gel scaffolds formed by the filamentous BDNF PA nanostructure. We tested six gel conditions including the BDNF PA, Linear BDNF PA, $\mathrm{E}_{4}$ PEG PA, $\mathrm{E}_{2}$ PA, and $\mathrm{E}_{2}$ PA encapsulating BDNF protein $\left(B D N F+E_{2}\right)$ or BDNF peptide (Peptide $+E_{2}$ ). All PA samples had similar nanofiber morphology and storage moduli relative to the $\mathrm{E}_{2} \mathrm{PA}$ as observed by scanning electron microscopy and rheological measurements respectively (Figure 5a-e and S13,14).

Furthermore, all the PA scaffolds had storage moduli ranging from 1.9 to $5.6 \mathrm{kPa}$, which are within the range of mechanical properties of neural tissue.

Gels were prepared using a commercial mold to maintain a uniform shape, size and degree of swelling (Figure S15). Neurons were then seeded on top of the gels for one week and were found to exhibit neurite extensions and a homogenous neuronal network in all gels tested (Figure $5 f$ and S16a-d). Neuronal cultures on BDNF PA gels and on BDNF $+\mathrm{E}_{2}$ PA gels exhibited a similar mature phenotype characterized by MAP-2 expression. The normalized average of MAP-2 intensity was found to be comparable in the BDNF PA gel $(0.64 \pm 0.15)$ and the BDNF $+\mathrm{E}_{2}$ PA gels $(0.55 \pm 0.08)$ (Figure S16e). However, MAP-2 expression was almost twice as high in these gels relative to $\mathrm{E}_{2} \mathrm{PA}$ gels $(0.32 \pm 0.06)$. Moreover, the distance that neurites infiltrated from the top of the scaffold was nearly fourand-a-half times higher in the BDNF PA scaffold $(179.7 \pm 6.0 \mu \mathrm{m})$ compared with all the other conditions (BDNF $+\mathrm{E}_{2}$ PA: $20.1 \pm 5.0 \mu \mathrm{m}$, Peptide $+\mathrm{E}_{2}$ PA: $28.34 \pm 4.5 \mu \mathrm{m}$, and $\mathrm{E}_{2}$ PA: $36.9 \pm 9.9 \mu \mathrm{m}$ ) (Figure $5 \mathrm{~g}, \mathrm{~h}$ and $\mathrm{S} 16 \mathrm{f}, \mathrm{g}$ ). It is well known that BDNF-TrkB signaling induces neuronal migration and chemotaxis in cortical neurons.' It also plays a significant role in axon guidance and growth during development and when applied after injury.' The greater neurite infiltration in BDNF PA gels could be partially explained by the BDNF sequence presentation throughout the whole gel. The low cell infiltration on the $\mathrm{BDNF}+\mathrm{E}_{2}$ PA and Peptide $+E_{2}$ PA gels might be associated to the release of both molecules into the media over time as seen in previous studies where a similarly sized and charged protein completely eluted from PA gels. The ability of the BDNF PA to induce neuronal migration, as well as dendritic and axonal infiltration, is another indication of the capacity of the bioactive nanostructure's mimicry.

Finally, we investigated whether the neurons cultured on the BDNF PA gels were functionally mature by measuring their action potentials. Cortical neurons were cultured for 
up to one week on BDNF PA gels, and patch-clamp recordings were performed in wholecell current-clamp mode. A higher number of action potentials relative to steps of current injection were observed in neurons cultured on BDNF PA $(7.7 \pm 2.4)$ and BDNF $+\mathrm{E}_{2} \mathrm{PA}$ $(9.4 \pm 3.7)$ gels relative to cells on the $\mathrm{E}_{2} \mathrm{PA}(1.7 \pm 0.8)$, indicative of a more excitable cell phenotype (Figure $5 \mathrm{i}, \mathrm{j}$ ). Collectively, the population and single-cell based electrophysiological recordings along with the immunostaining suggested that neurons on the BDNF PA gels form a connected network of mature neurons capable of propagating electrical information.

We reported here on the synthesis and characterization of a peptide amphiphile supramolecular nanostructure displaying a BDNF mimetic peptide that induces biological responses similar to those of the native BDNF protein. The therapeutic potential of BDNF has been tested in several in vivo studies and clinical trials for neurologic conditions over the past several decades., , , Several studies investigating small synthetic peptide mimetics, and small molecule ligands based on the BDNF and TrkB receptor interaction have been shown to promote survival, axonal regrowth, and maturation of neural cells using both in vitro and in vivo models., , - One example of such systems is a peptide known as RADA16 functionalized with a neurotrophic peptide derived from BDNF, however, these studies have not demonstrated activation of the TrkB receptor and its downstream signaling cascades.' In the supramolecular nanostructure investigated here, this activation has been clearly demonstrated as well as the enhancement of neuronal electrical activity in 2D and 3D cultures.

A key finding of our study has been the observation that the BDNF mimetic peptide used was only bioactive when displayed on a peptide amphiphile supramolecular nanofiber. In fact, as previously discussed, we showed that use of the specific $\mathrm{PEG}_{6}$ linker in our PA monomer was not sufficient to induce the observed supramolecular bioactivity. We speculate that single PA monomers or clusters of the supramolecular scaffold are able to create optimal adaptive configurations to interact with receptors in the highly dynamic environment of the cell. A specific mechanism could be the partial fragmentation of the long high aspect ratio supramolecular nanofibers to enhance receptor-signal interactions. This would facilitate the ability of the fiber to dimerize and also cluster receptors for effective TrkB receptor activation. In this context it is clear that these mechanisms would not be available to molecules bound by covalent bonds in either macromolecules or functionalized particles. The elucidation of these mechanistic details will require future studies using highly advanced imaging methodologies, some of which may not be fully developed yet.

We conclude that the BDNF PA supramolecular nanostructure investigated here was able to induce the activation of not only the TrkB receptor but also its downstream signaling cascades responsible for cell survival, growth and functional maturation in 2D cultures. Furthermore, the gels formed by the BDNF PA nanostructures encourage neuronal cell infiltration in 3D while increasing maturation and functional electrical activity after 1 week in vitro. This observation suggests the possibility of using these soft nanostructures to help promote regeneration or engraftment of transplanted cells in the CNS. 


\section{Supplementary Material}

Refer to Web version on PubMed Central for supplementary material.

\section{ACKNOWLEDGMENTS}

We are grateful to the following core facilities at Northwestern University: the Peptide Synthesis Core and the Analytical Bionanotechnology Equipment Core both at the Simpson Querrey Institute for BioNanotechnology. The U.S. Army Research Office, the U.S. Army Medical Research Materiel Command, and Northwestern University provided funding to develop these facilities and ongoing support is being received from the Soft and Hybrid Nanotechnology Experimental (SHyNE) Resource (NSF NNCI-1542205). The Biological Imaging Facility (supported by the Northwestern University Office for Research), the Center for Advanced Microscopy (NCI CCSG P30 CA060553), Flow Cytometry Core (supported by Cancer Center Support Grant NCI CA060553), the Electron Probe Instrumentation Center (EPIC) facility of Northwestern University's NUANCE Center, which has received support from the Soft and Hybrid Nanotechnology Experimental (SHyNE) Resource (NSF ECCS-1542205), and this work made use of the Integrated Molecular Structure Education and Research Center (IMSERC) at Northwestern University, which has received support from the Soft and Hybrid Nanotechnology Experimental (SHyNE) Resource (NSF ECCS-1542205); the State of Illinois and International Institute for Nanotechnology (IIN). Portions of this work were performed at the DuPont-Northwestern-Dow Collaborative Access Team (DNDCAT) located at Sector 5 of the Advanced Photon Source (APS). DND-CAT is supported by Northwestern University, E.I. DuPont de Nemours \& Co., and The Dow Chemical Company. This research used resources of the Advanced Photon Source, a U.S. Department of Energy (DOE) Office of Science User Facility operated for the DOE Office of Science by Argonne National Laboratory under Contract No. DE-AC02-06CH11357. The authors also thank Prof. Alfred George for the use of his facilities for all patch clamp experiments, Armando Hernandez Garcia for assistance with flow cytometry experiments, Prof. Liam Palmer for helpful discussions, as well as Jack Edelbrock and Mark Seniw for their design of schematic drawings in the manuscript. The authors would also like to thank Dr. Iván Sasselli for his assistance with all FTIR experiments.

Funding Sources

This work was supported by National Institutes of Health/National Institute of Biomedical Imaging and Bioengineering Award Number 5R01EB003806-07 and by the Center for Regenerative Nanomedicine at the Simpson Querrey Institute at Northwestern. The E.K. lab is supported by research grants from the Les Turner ALS Foundation, the Muscular Dystrophy Association, the Dravet Foundation and NIH/NINDS R01NS104219. EK is a Les Turner ALS Center Investigator. A.N.E. and S.M.C. received graduate research fellowships through the National Science Foundation. Z.A. received postdoctoral support from the Beatriu de Pinós Fellowship 2014 BP-A 00007 (Agència de Gestió d'Ajust Universitaris i de Recerca, AGAUR) and the PVA Grant \# PVA17_RF_0008 from the Paralyzed Veterans of America (PVA) Research Foundation.

\section{ABBREVIATIONS}

AKT

APTES

BDNF

CNS

Cryo-TEM

DAPI

DLS

EDC

ERK 1/2

FGF-2 serine/threonine specific protein kinase

(3-Aminopropyl)triethoxysilane

brain derived neurotrophic factor

central nervous system

cryogenic transmission electron microscopy

4',6-diamidino-2-phenylindole

dynamic light scattering

1-Ethyl-3-(3-dimethylaminopropyl)carbodiimide

extracellular signal-regulated kinase 1/2

fibroblast growth factor 2 


\begin{tabular}{|c|c|}
\hline FGFR-1 & fibroblast growth factor receptor 1 \\
\hline IKVAV & isoleucine-lysine-valine-alanine-valine \\
\hline MAP-2 & microtubule-associated protein 2 \\
\hline МАРК & mitogen-activated protein kinase \\
\hline MEA & multielectrode array \\
\hline NGF & nerve growth factor \\
\hline NT-3 & neurotrophin 3 \\
\hline NT-4 & neurotrophin 4 \\
\hline PA & peptide amphiphile \\
\hline $\mathbf{p A K T}$ & phosphorylated serine/threonine specific protein kinase \\
\hline PDL & poly-D-lysine \\
\hline pERK 1/2 & phosphorylated extracellular signal-regulated kinase \\
\hline PI3K & phosphoinositide 3-kinase \\
\hline PLC $\gamma$ & phospholipase $\mathrm{C}$ gamma \\
\hline PSD95 & postsynaptic density protein 95 \\
\hline pTrkB & phosphorylated tyrosine kinase B \\
\hline SAXS & small angle $\mathrm{x}$-ray scattering \\
\hline SEM & scanning electron microscopy \\
\hline TrkB & tyrosine kinase B \\
\hline VEGF & vascular endothelial growth factor \\
\hline VEGFR-1 & vascular endothelial growth factor receptor 1 \\
\hline
\end{tabular}

\section{References}

1. Nagahara AH; Tuszynski MH, Potential therapeutic uses of BDNF in neurological and psychiatric disorders. Nature Reviews Drug Discovery 2011, 10 (3), 209-219. [PubMed: 21358740]

2. Marshall J; Szmydynger-Chodobska J; Rioult-Pedotti MS; Lau K; Chin AT; Kotla SKR; Tiwari RK; Parang K; Threlkeld SW; Chodobski A, TrkB-enhancer facilitates functional recovery after traumatic brain injury. Sci Rep 2017, 7 (1), 10995. [PubMed: 28887487]

3. Mantilla CB; Gransee HM; Zhan WZ; Sieck GC, Motoneuron BDNF/TrkB signaling enhances functional recovery after cervical spinal cord injury. Exp Neurol 2013, 247, 101-9. [PubMed: 23583688]

4. Costa A; Peppe A; Carlesimo GA; Zabberoni S; Scalici F; Caltagirone C; Angelucci F, Brainderived neurotrophic factor serum levels correlate with cognitive performance in Parkinson's disease patients with mild cognitive impairment. Front Behav Neurosci 2015, 9, 253. [PubMed: 26441580] 
5. Lu B; Pang PT; Woo NH, The yin and yang of neurotrophin action. Nat Rev Neurosci 2005, 6 (8), 603-14. [PubMed: 16062169]

6. Chao MV, Neurotrophins and their receptors: a convergence point for many signalling pathways. Nat Rev Neurosci 2003, 4 (4), 299-309. [PubMed: 12671646]

7. Park H; Poo MM, Neurotrophin regulation of neural circuit development and function. Nat Rev Neurosci 2013, 14 (1), 7-23. [PubMed: 23254191]

8. Lu P; Jones LL; Tuszynski MH, BDNF-expressing marrow stromal cells support extensive axonal growth at sites of spinal cord injury. Exp Neurol 2005, 191 (2), 344-60. [PubMed: 15649491]

9. Huang EJ; Reichardt LF, Trk receptors: roles in neuronal signal transduction. Annu Rev Biochem 2003, 72, 609-42. [PubMed: 12676795]

10. Gentry JJ; Barker PA; Carter BD, The p75 neurotrophin receptor: multiple interactors and numerous functions. Prog Brain Res 2004, 146, 25-39. [PubMed: 14699954]

11. Lu B; Nagappan G; Guan X; Nathan PJ; Wren P, BDNF-based synaptic repair as a diseasemodifying strategy for neurodegenerative diseases. Nat Rev Neurosci 2013, 14 (6), 401-16. [PubMed: 23674053]

12. Barde YA; Edgar D; Thoenen H, Purification of a new neurotrophic factor from mammalian brain. EMBO J 1982, 1 (5), 549-53. [PubMed: 7188352]

13. Nagahara AH; Merrill DA; Coppola G; Tsukada S; Schroeder BE; Shaked GM; Wang L; Blesch A; Kim A; Conner JM; Rockenstein E; Chao MV; Koo EH; Geschwind D; Masliah E; Chiba AA; Tuszynski MH, Neuroprotective effects of brain-derived neurotrophic factor in rodent and primate models of Alzheimer's disease. Nat Med 2009, 15 (3), 331-7. [PubMed: 19198615]

14. Budni J; Bellettini-Santos T; Mina F; Garcez ML; Zugno AI, The involvement of BDNF, NGF and GDNF in aging and Alzheimer's disease. Aging Dis 2015, 6 (5), 331-41. [PubMed: 26425388]

15. Tanaka J; Horiike Y; Matsuzaki M; Miyazaki T; Ellis-Davies GC; Kasai H, Protein synthesis and neurotrophin-dependent structural plasticity of single dendritic spines. Science 2008, 319 (5870), 1683-7. [PubMed: 18309046]

16. Pardridge WM, Neurotrophins, neuroprotection and the blood-brain barrier. Curr Opin Investig Drugs 2002, 3 (12), 1753-7.

17. Ochs G; Penn RD; York M; Giess R; Beck M; Tonn J; Haigh J; Malta E; Traub M; Sendtner M; Toyka KV, A phase I/II trial of recombinant methionyl human brain derived neurotrophic factor administered by intrathecal infusion to patients with amyotrophic lateral sclerosis. Amyotroph Lateral Scler Other Motor Neuron Disord 2000, 1 (3), 201-6. [PubMed: 11464953]

18. Wellmer A; Misra VP; Sharief MK; Kopelman PG; Anand P, A double-blind placebo-controlled clinical trial of recombinant human brain-derived neurotrophic factor (rhBDNF) in diabetic polyneuropathy. J Peripher Nerv Syst 2001, 6 (4), 204-10. [PubMed: 11800042]

19. Thoenen H; Sendtner M, Neurotrophins: from enthusiastic expectations through sobering experiences to rational therapeutic approaches. Nat Neurosci 2002, 5 Suppl, 1046-50. [PubMed: 12403983]

20. Wang L; Ying T, New Directions for Half-Life Extension of Protein Therapeutics: The Rise of Antibody Fc Domains and Fragments. Curr Pharm Biotechnol 2016, 17 (15), 1348-1352. [PubMed: 27552847]

21. Webber MJ; Tongers J; Newcomb CJ; Marquardt KT; Bauersachs J; Losordo DW; Stupp SI, Supramolecular nanostructures that mimic VEGF as a strategy for ischemic tissue repair. Proc Natl Acad Sci U S A 2011, 108 (33), 13438-43. [PubMed: 21808036]

22. Massa SM; Yang T; Xie Y; Shi J; Bilgen M; Joyce JN; Nehama D; Rajadas J; Longo FM, Small molecule BDNF mimetics activate TrkB signaling and prevent neuronal degeneration in rodents. J Clin Invest 2010, 120 (5), 1774-85. [PubMed: 20407211]

23. O'Leary PD; Hughes RA, Design of potent peptide mimetics of brain-derived neurotrophic factor. Journal of Biological Chemistry 2003, 278 (28), 25738-25744. [PubMed: 12730196]

24. O'Leary PD; Hughes RA, Structure-activity relationships of conformationally constrained peptide analogues of loop 2 of brain-derived neurotrophic factor. J Neurochem 1998, 70 (4), 1712-21. [PubMed: 9523590]

25. Fletcher JM; Hughes RA, Novel monocyclic and bicyclic loop mimetics of brain-derived neurotrophic factor. Journal of Peptide Science 2006, 12 (8), 515-524. [PubMed: 16680799] 
26. Fletcher JM; Morton CJ; Zwar RA; Murray SS; O’Leary PD; Hughes RA, Design of a Conformationally Defined and Proteolytically Stable Circular Mimetic of Brain-derived Neurotrophic Factor. Journal of Biological Chemistry 2008, 283 (48), 33375-33383. [PubMed: 18809686]

27. Gonsalvez DG; Tran G; Fletcher JL; Hughes RA; Hodgkinson S; Wood RJ; Yoo SW; De Silva M; Agnes WW; McLean C; Kennedy P; Kilpatrick TJ; Murray SS; Xiao J, A Brain-Derived Neurotrophic Factor-Based p75NTR Peptide Mimetic Ameliorates Experimental Autoimmune Neuritis Induced Axonal Pathology and Demyelination. eNeuro 2017, 4 (3).

28. Freeman R; Stephanopoulos N; Álvarez Z; Lewis JA; Sur S; Serrano CM; Boekhoven J; Lee SS; Stupp SI, Instructing cells with programmable peptide DNA hybrids. Nat Commun 2017, 8, 15982. [PubMed: 28691701]

29. Hartgerink JD; Beniash E; Stupp SI, Self-assembly and mineralization of peptide-amphiphile nanofibers. Science 2001, 294 (5547), 1684-8. [PubMed: 11721046]

30. Hendricks MP; Sato K; Palmer LC; Stupp SI, Supramolecular Assembly of Peptide Amphiphiles. Acc Chem Res 2017, 50 (10), 2440-2448. [PubMed: 28876055]

31. Silva GA; Czeisler C; Niece KL; Beniash E; Harrington DA; Kessler JA; Stupp SI, Selective differentiation of neural progenitor cells by high-epitope density nanofibers. Science 2004, 303 (5662), 1352-1355. [PubMed: 14739465]

32. Lee SS; Fyrner T; Chen F; Álvarez Z; Sleep E; Chun DS; Weiner JA; Cook RW; Freshman RD; Schallmo MS; Katchko KM; Schneider AD; Smith JT; Yun C; Singh G; Hashmi SZ; McClendon MT; Yu Z; Stock SR; Hsu WK; Hsu EL; Stupp SI, Sulfated glycopeptide nanostructures for multipotent protein activation. Nat Nanotechnol 2017, 12 (8), 821-829. [PubMed: 28650443]

33. Sleep E; Cosgrove BD; McClendon MT; Preslar AT; Chen CH; Sangji MH; Pérez CMR; Haynes RD; Meade TJ; Blau HM; Stupp SI, Injectable biomimetic liquid crystalline scaffolds enhance muscle stem cell transplantation. Proc Natl Acad Sci U S A 2017, 114 (38), E7919-E7928. [PubMed: 28874575]

34. Pan L; North HA; Sahni V; Jeong SJ; McGuire TL; Berns EJ; Stupp SI; Kessler JA, beta1-Integrin and integrin linked kinase regulate astrocytic differentiation of neural stem cells. PLoS One 2014, 9 (8), e104335. [PubMed: 25098415]

35. Berns EJ; Álvarez Z; Goldberger JE; Boekhoven J; Kessler JA; Kuhn HG; Stupp SI, A tenascin-C mimetic peptide amphiphile nanofiber gel promotes neurite outgrowth and cell migration of neurosphere-derived cells. Acta Biomater 2016, 37, 50-8. [PubMed: 27063496]

36. Rubert Pérez CM; Álvarez Z; Chen F; Aytun T; Stupp SI, Mimicking the Bioactivity of Fibroblast Growth Factor-2 Using Supramolecular Nanoribbons. ACS Biomater Sci Eng 2017, 3 (9), 2166 2175. [PubMed: 28920077]

37. Fletcher JM; Hughes RA, Modified low molecular weight cyclic peptides as mimetics of BDNF with improved potency, proteolytic stability and transmembrane passage in vitro. Bioorganic \& Medicinal Chemistry 2009, 17 (7), 2695-2702. [PubMed: 19303307]

38. Sur S; Tantakitti F; Matson JB; Stupp SI, Epitope topography controls bioactivity in supramolecular nanofibers. Biomater Sci 2015, 3 (3), 520-32. [PubMed: 26222295]

39. Goldberger JE; Berns EJ; Bitton R; Newcomb CJ; Stupp SI, Electrostatic control of bioactivity. Angew Chem Int Ed Engl 2011, 50 (28), 6292-5. [PubMed: 21626619]

40. Tantakitti F; Boekhoven J; Wang X; Kazantsev RV; Yu T; Li J; Zhuang E; Zandi R; Ortony JH; Newcomb CJ; Palmer LC; Shekhawat GS; de la Cruz MO; Schatz GC; Stupp SI, Energy landscapes and functions of supramolecular systems. Nat Mater 2016, 15 (4), 469-76. [PubMed: 26779883]

41. Rodriguez-Tébar A; Dechant G; Barde YA, Binding of brain-derived neurotrophic factor to the nerve growth factor receptor. Neuron 1990, 4 (4), 487-92. [PubMed: 2157470]

42. Burkhalter J; Fiumelli H; Allaman I; Chatton JY; Martin JL, Brain-derived neurotrophic factor stimulates energy metabolism in developing cortical neurons. J Neurosci 2003, 23 (23), 8212-20. [PubMed: 12967982]

43. Ji Y; Pang PT; Feng L; Lu B, Cyclic AMP controls BDNF-induced TrkB phosphorylation and dendritic spine formation in mature hippocampal neurons. Nat Neurosci 2005, 8 (2), 164-72. [PubMed: 15665879] 
44. Brewer GJ, Serum-free B27/neurobasal medium supports differentiated growth of neurons from the striatum, substantia nigra, septum, cerebral cortex, cerebellum, and dentate gyrus. J Neurosci Res 1995, 42 (5), 674-83. [PubMed: 8600300]

45. Tapley P; Lamballe F; Barbacid M, K252a is a selective inhibitor of the tyrosine protein kinase activity of the trk family of oncogenes and neurotrophin receptors. Oncogene 1992, 7 (2), 371-81. [PubMed: 1312698]

46. Pereira Gomes C; Leiro V; Daniela Ferreira Lopes C; Patrícia Spencer A; Paula Pêgo A, Fine tuning neuronal targeting of nanoparticles by adjusting the ligand grafting density and combining PEG spacers of different length. Acta Biomaterialia 2018.

47. Pallarola D; Bochen A; Boehm H; Rechenmacher F; Sobahi TR; Spatz JP; Kessler H, Interface Immobilization Chemistry of $c$ RGD-based Peptides Regulates Integrin Mediated Cell Adhesion. Adv Funct Mater 2014, 24 (7), 943-956. [PubMed: 25810710]

48. Guler MO; Soukasene S; Hulvat JF; Stupp SI, Presentation and recognition of biotin on nanofibers formed by branched peptide amphiphiles. Nano Lett 2005, 5 (2), 249-52. [PubMed: 15794605]

49. Olbrich KC; Andersen TT; Blumenstock FA; Bizios R, Surfaces modified with covalentlyimmobilized adhesive peptides affect fibroblast population motility. Biomaterials 1996, 17 (8), 759-64. [PubMed: 8730959]

50. Martínez A; Alcántara S; Borrell V; Del Río JA; Blasi J; Otal R; Campos N; Boronat A; Barbacid M; Silos-Santiago I; Soriano E, TrkB and TrkC signaling are required for maturation and synaptogenesis of hippocampal connections. J Neurosci 1998, 18 (18), 7336-50. [PubMed: 9736654]

51. Ji Y; Lu Y; Yang F; Shen W; Tang TT; Feng L; Duan S; Lu B, Acute and gradual increases in BDNF concentration elicit distinct signaling and functions in neurons. Nat Neurosci 2010, 13 (3), 302-9. [PubMed: 20173744]

52. Cohen-Cory S; Kidane AH; Shirkey NJ; Marshak S, Brain-derived neurotrophic factor and the development of structural neuronal connectivity. Dev Neurobiol 2010, 70 (5), 271-88. [PubMed: 20186709]

53. Gorski JA; Zeiler SR; Tamowski S; Jones KR, Brain-derived neurotrophic factor is required for the maintenance of cortical dendrites. J Neurosci 2003, 23 (17), 6856-65. [PubMed: 12890780]

54. Gottschalk WA; Jiang H; Tartaglia N; Feng L; Figurov A; Lu B, Signaling mechanisms mediating BDNF modulation of synaptic plasticity in the hippocampus. Learn Mem 1999, 6 (3), 243-56. [PubMed: 10492006]

55. Okada D; Yamagishi S; Sugiyama H, Differential effects of phospholipase inhibitors in long-term potentiation in the rat hippocampal mossy fiber synapses and Schaffer/commissural synapses. Neurosci Lett 1989, 100 (1-3), 141-6. [PubMed: 2761761]

56. Thomas GM; Huganir RL, MAPK cascade signalling and synaptic plasticity. Nat Rev Neurosci 2004, 5 (3), 173-83. [PubMed: 14976517]

57. Yoshii A; Constantine-Paton M, Postsynaptic BDNF-TrkB signaling in synapse maturation, plasticity, and disease. Dev Neurobiol 2010, 70 (5), 304-22. [PubMed: 20186705]

58. Huang EJ; Reichardt LF, Neurotrophins: Roles in Neuronal Development and Function. Annual Review of Neuroscience 2001, 24 (1), 677-736.

59. Kellner Y; Gödecke N; Dierkes T; Thieme N; Zagrebelsky M; Korte M, The BDNF effects on dendritic spines of mature hippocampal neurons depend on neuronal activity. Front Synaptic Neurosci 2014, 6, 5. [PubMed: 24688467]

60. Guo W; Ji Y; Wang S; Sun Y; Lu B, Neuronal activity alters BDNF-TrkB signaling kinetics and downstream functions. J Cell Sci 2014, 127 (Pt 10), 2249-60. [PubMed: 24634513]

61. Dehmelt L; Halpain S, The MAP2/Tau family of microtubule-associated proteins. Genome Biol 2005, 6 (1), 204. [PubMed: 15642108]

62. Meyer D; Bonhoeffer T; Scheuss V, Balance and stability of synaptic structures during synaptic plasticity. Neuron 2014, 82 (2), 430-43. [PubMed: 24742464]

63. Discher DE; Mooney DJ; Zandstra PW, Growth factors, matrices, and forces combine and control stem cells. Science 2009, 324 (5935), 1673-7. [PubMed: 19556500] 
64. Chiaramello S; Dalmasso G; Bezin L; Marcel D; Jourdan F; Peretto P; Fasolo A; De Marchis S, $\mathrm{BDNF} / \mathrm{TrkB}$ interaction regulates migration of SVZ precursor cells via PI3-K and MAP-K signalling pathways. Eur J Neurosci 2007, 26 (7), 1780-90. [PubMed: 17883412]

65. Behar TN; Dugich-Djordjevic MM; Li YX; Ma W; Somogyi R; Wen X; Brown E; Scott C; McKay RD; Barker JL, Neurotrophins stimulate chemotaxis of embryonic cortical neurons. Eur J Neurosci 1997, 9 (12), 2561-70. [PubMed: 9517461]

66. Huang EJ; Reichardt LF, Neurotrophins: roles in neuronal development and function. Annu Rev Neurosci 2001, 24, 677-736. [PubMed: 11520916]

67. Blesch A; Tuszynski MH, Transient growth factor delivery sustains regenerated axons after spinal cord injury. Journal of Neuroscience 2007, 27 (39), 10535-10545. [PubMed: 17898225]

68. McTigue DM; Horner PJ; Stokes BT; Gage FH, Neurotrophin-3 and brain-derived neurotrophic factor induce oligodendrocyte proliferation and myelination of regenerating axons in the contused adult rat spinal cord. Journal of Neuroscience 1998, 18 (14), 5354-5365. [PubMed: 9651218]

69. Ramos-Cejudo J; Gutiérrez-Fernández M; Otero-Ortega L; Rodríguez-Frutos B; Fuentes B; Vallejo-Cremades MT; Hernanz TN; Cerdán S; Díez-Tejedor E, Brain-derived neurotrophic factor administration mediated oligodendrocyte differentiation and myelin formation in subcortical ischemic stroke. Stroke 2015, 46 (1), 221-8. [PubMed: 25395417]

70. Adessi C; Soto C, Converting a peptide into a drug: strategies to improve stability and bioavailability. Curr Med Chem 2002, 9 (9), 963-78. [PubMed: 11966456]

71. Fobian K; Owczarek S; Budtz C; Bock E; Berezin V; Pedersen MV, Peptides derived from the solvent-exposed loops 3 and 4 of BDNF bind TrkB and p75(NTR) receptors and stimulate neurite outgrowth and survival. J Neurosci Res 2010, 88 (6), 1170-81. [PubMed: 19908279]

72. Wong AW; Giuffrida L; Wood R; Peckham H; Gonsalvez D; Murray SS; Hughes RA; Xiao J, TDP6, a brain-derived neurotrophic factor-based trkB peptide mimetic, promotes oligodendrocyte myelination. Mol Cell Neurosci 2014, 63, 132-40. [PubMed: 25461619]

73. Fon D; Zhou K; Ercole F; Fehr F; Marchesan S; Minter MR; Crack PJ; Finkelstein DI; Forsythe JS, Nanofibrous scaffolds releasing a small molecule BDNF-mimetic for the re-direction of endogenous neuroblast migration in the brain. Biomaterials 2014, 35 (9), 2692-712. [PubMed: 24406218]

74. Lu J; Sun X; Yin H; Shen X; Yang S; Wang Y; Jiang W; Sun Y; Zhao L; Sun X; Lu S; Mikos AG; Peng J; Wang X, A neurotrophic peptide-functionalized self-assembling peptide nanofiber hydrogel enhances rat sciatic nerve regeneration. Nano Research 2018, 11 (9), 4599-4613.

75. Shi W; Huang CJ; Xu XD; Jin GH; Huang RQ; Huang JF; Chen YN; Ju SQ; Wang Y; Shi YW; Qin JB; Zhang YQ; Liu QQ; Wang XB; Zhang XH; Chen J, Transplantation of RADA16-BDNF peptide scaffold with human umbilical cord mesenchymal stem cells forced with CXCR4 and activated astrocytes for repair of traumatic brain injury. Acta Biomater 2016, 45, 247-261. [PubMed: 27592818]

76. Aida T; Meijer EW; Stupp SI, Functional supramolecular polymers. Science 2012, 335 (6070), 813-7. [PubMed: 22344437] 
a

BDNF Mimetic

Peptide

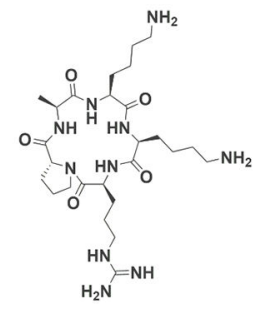

b
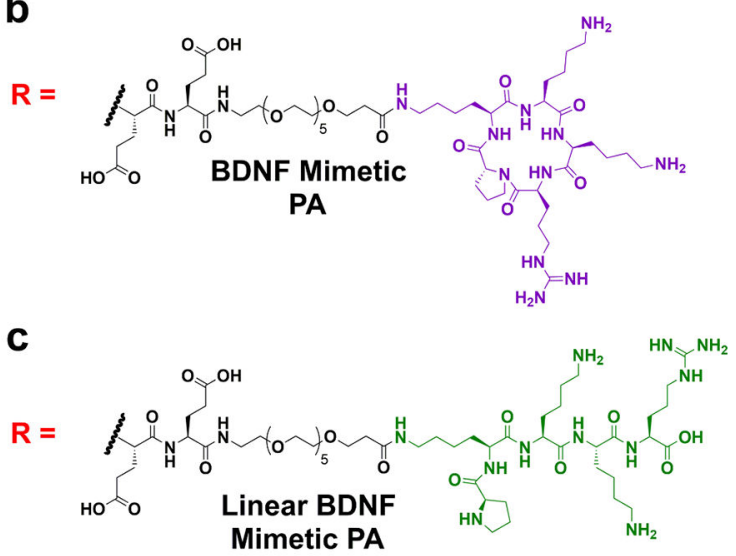

d
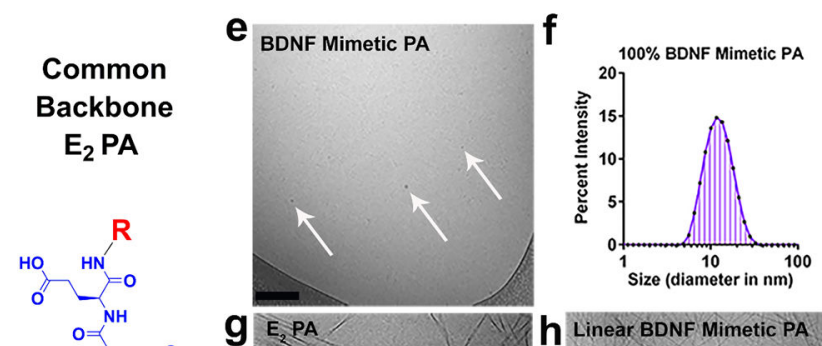

$\stackrel{O}{2}$

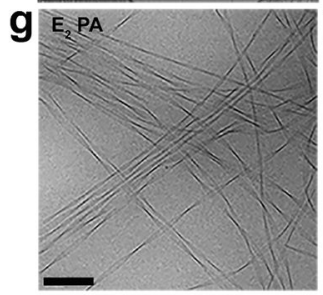

h Linear BDNF Mimetic PA $10 \mathrm{~mol} \%$
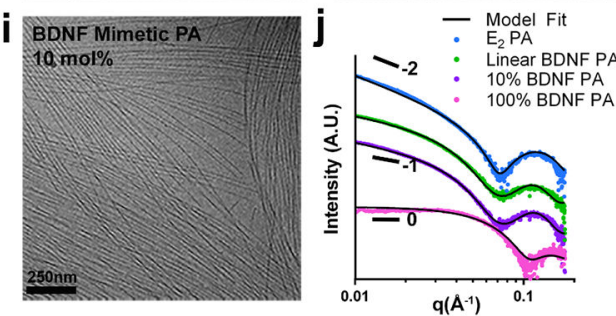

Figure 1. Design and characterization of BDNF mimetic peptide amphiphiles (PAs). (a-d) Chemical structures of (a) the cyclic BDNF mimetic peptide, (b) BDNF PA, (c) Linear BDNF PA and (d) $E_{2}$ PA when $R=H$. (e) Cryo-TEM and (f) dynamic light scattering of BDNF PA spherical nanostructures at $100 \mathrm{~mol} \%$ with an average diameter of $\sim 12 \mathrm{~nm}$. (g-i) Cryo-TEM of $\mathrm{E}_{2}$ PA (g) at $100 \mathrm{~mol} \%$, Linear BDNF PA (h) and BDNF PA (i), both coassembled at $10 \mathrm{~mol} \%$ with $\mathrm{E}_{2}$ PA. (j) Small angle $\mathrm{x}$-ray scattering curves of PAs corresponding to $\mathrm{E}_{2} \mathrm{PA}$ (blue), Linear BDNF PA (green), BDNF mimetic PA co-assembled with $\mathrm{E}_{2} \mathrm{PA}$ at $10 \mathrm{~mol} \%$ (purple), pure BDNF PA (pink) and the model fit of each curve (black). 
a

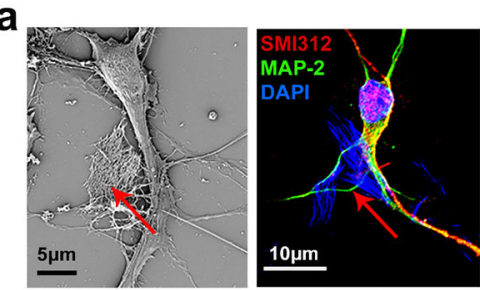

f

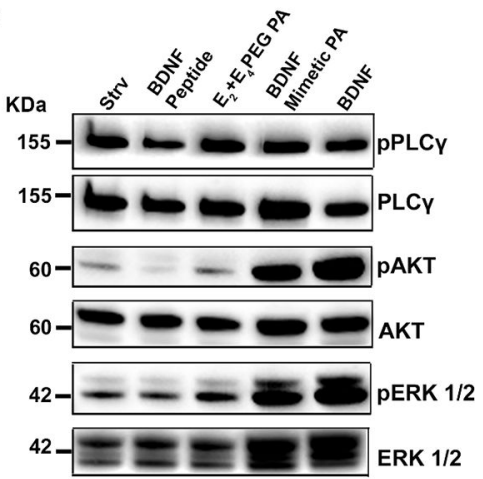

b

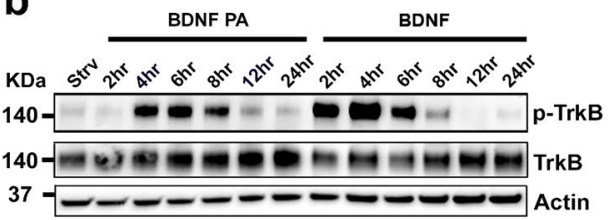

d

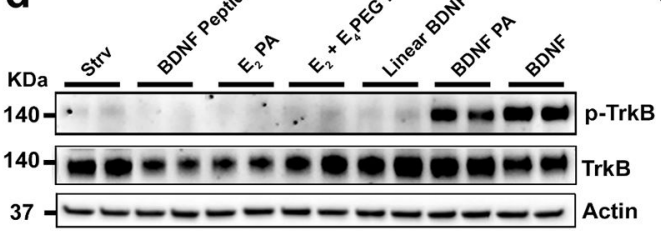

g

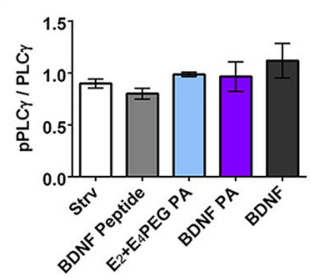

C

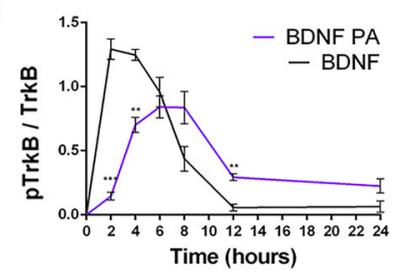

e

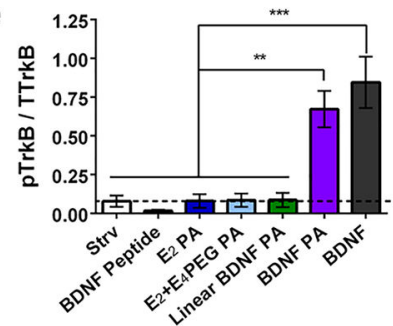

Figure 2. TrKB receptor activation and downstream pathway analysis in primary cortical neurons treated with BDNF PA.

(a) SEM micrograph (left) and confocal micrograph (right) showing a cortical neuron treated with PA nanofibers (red arrows and areas colored in blue). Cells were stained for SMI312 (axonal marker, red), MAP-2 (dendritic marker, green), and DAPI (nuclei, blue); DAPI also stains the PA. (b) Western blot of phosphorylated TrkB (p-TrkB), TrkB, and actin in neural cells exposed to BDNF PA and BDNF protein over a period of $24 \mathrm{~h}$ in vitro. starvation media (Strv) was used as a negative control. (c) Plot of the fraction of TrkB that is phosphorylated based on densitometry analysis of the western blot shown in (b) as a function of time. (d) Western blot of p-TrkB, and total TrKB receptor in neural cells treated with Strv, BDNF Peptide, different PA conditions ( $\mathrm{E}_{2} \mathrm{PA}, \mathrm{E}_{2}+\mathrm{E}_{4} \mathrm{PEG}$, Linear BDNF and BDNF PA) and BDNF protein for $6 \mathrm{~h}$ in vitro. Western blot shows duplicate samples for each condition. (e) Bar graph based on densitometry analysis of the western blot in (d) quantifying the fraction of p-TrkB after exposure of cultures to the treatments indicated. (f) Western blot of markers for downstream pathways triggered by TrkB activation: PLC $\gamma$, AKT and ERK 1/2 for neural cells treated with Strv, BDNF peptide, $\mathrm{E}_{2}+\mathrm{E}_{4}$ PEG PA, BDNF PA, and BDNF protein for $6 \mathrm{~h}$ in vitro. $(\mathrm{g})$ Bar graphs quantifying through densitometry analysis of phosphorylated proteins normalized to total protein shown in (f). $* \mathrm{P}<0.05$, $* * \mathrm{P}<0.01$, $* * \mathrm{P}<0.001$, and $* * * * \mathrm{P}<0.0001$, LSD test $(\mathrm{b}-\mathrm{g})(\mathrm{n}=3)$. 
a
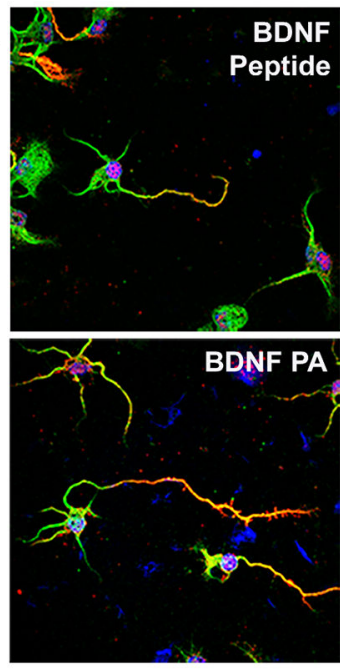

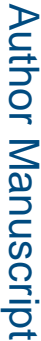

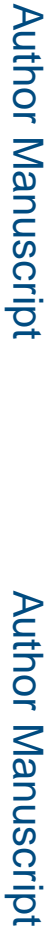

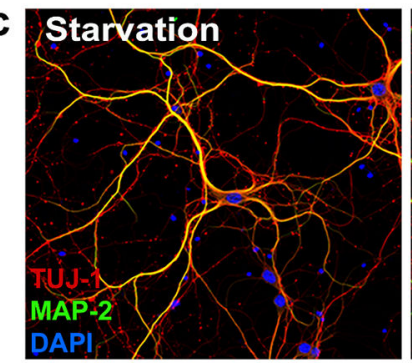

d
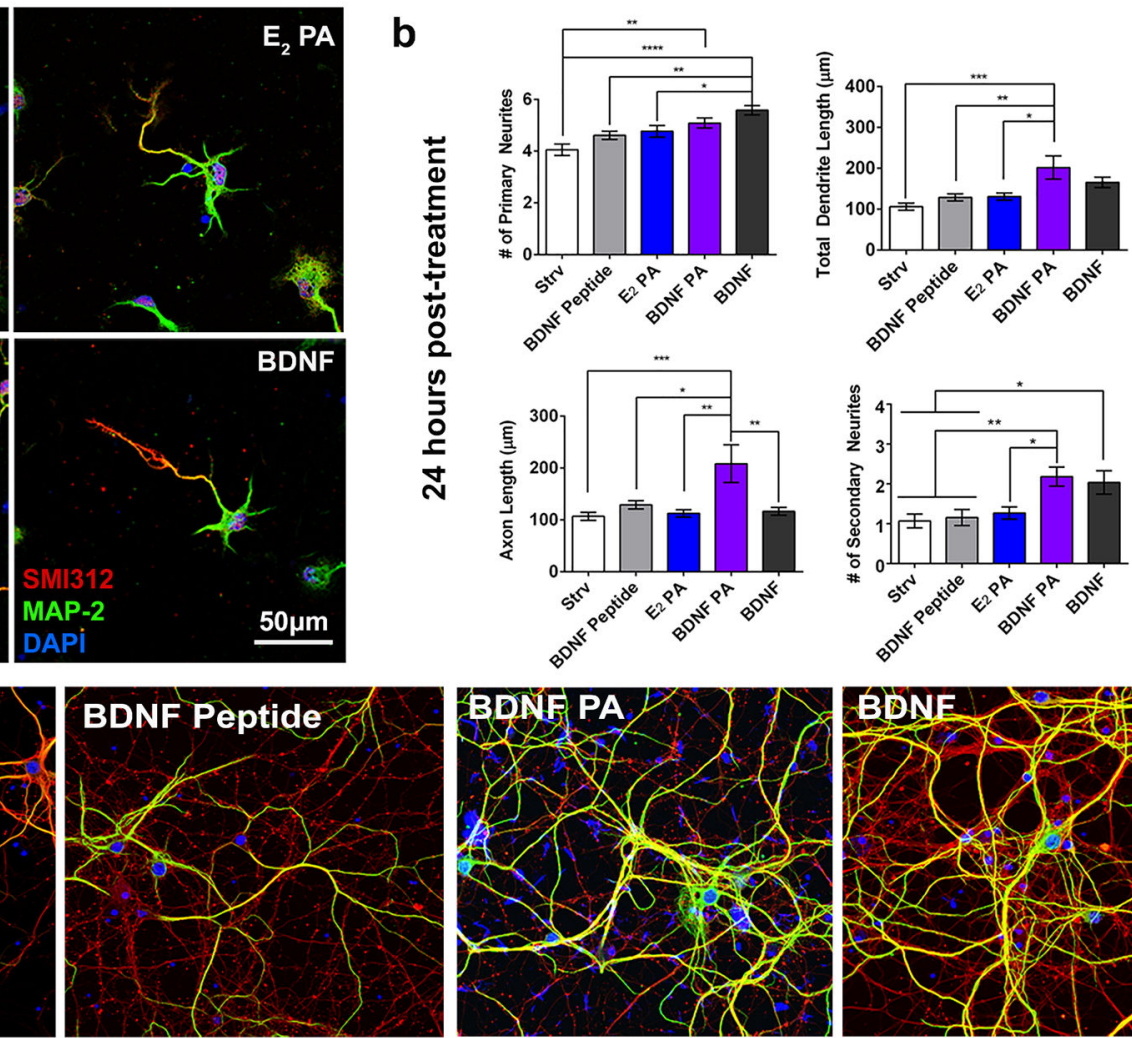

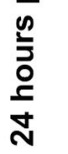
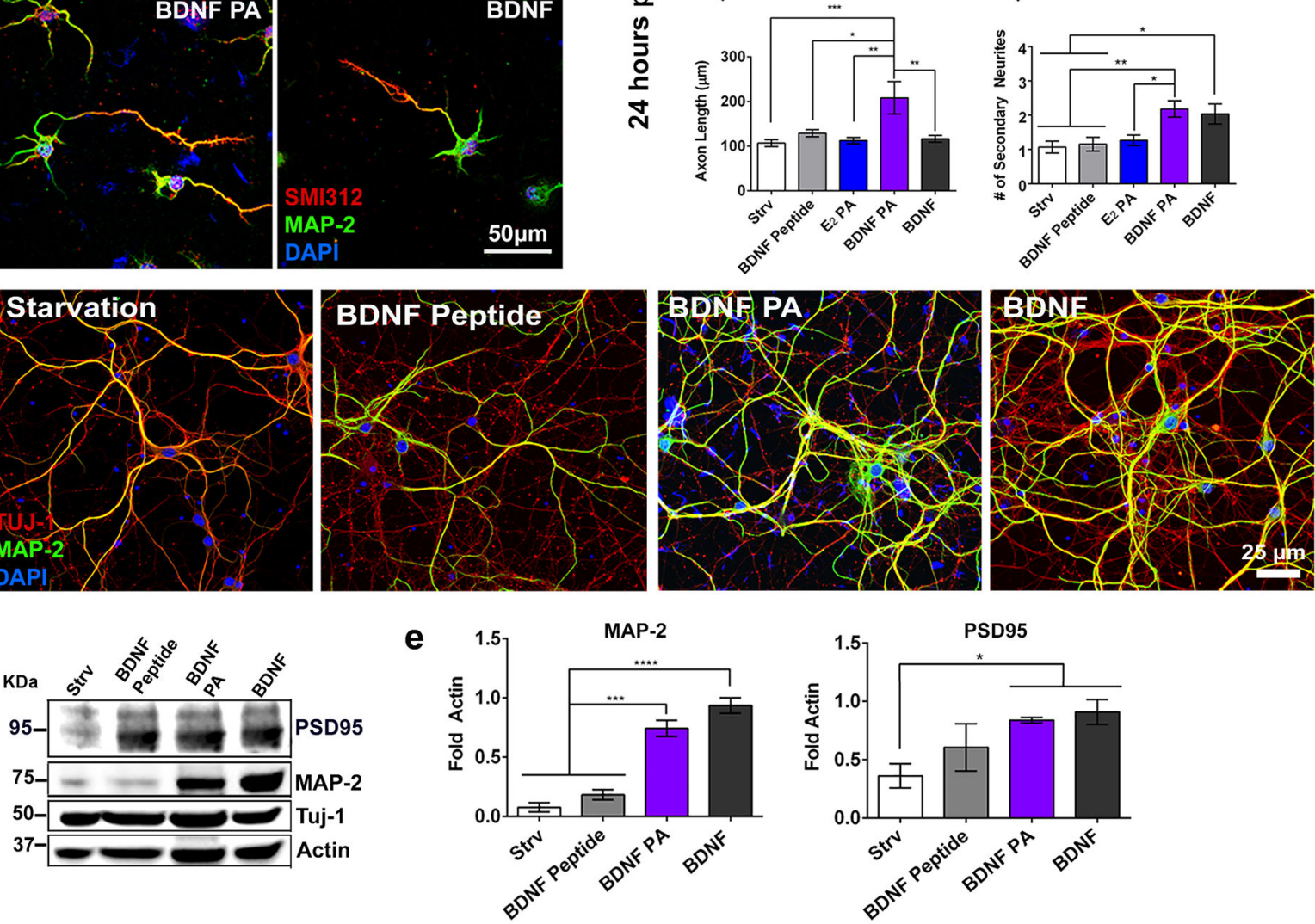

Figure 3. Morphometric analysis and cell maturation.

(a) Confocal images of neuronal cells treated with BDNF Peptide, E2 PA, BDNF PA, and BDNF protein for 24h in vitro (cells were stained with the axonal marker SMI312 (red), dendritic marker MAP-2 (green), and nucleus as well as PA marker DAPI (blue). (b)

Morphometric analysis for neural cells treated with starvation media (Strv), BDNF peptide, $\mathrm{E}_{2}$ PA, BDNF PA and BDNF protein for 24h. (c) Confocal microscopy images of neuronal cells treated with starvation media (Strv), BDNF peptide, BDNF PA, and BDNF protein during 2 weeks in vitro. Cells were stained for MAP-2 (dendritic marker, green), TUJ-1 (neuronal marker, red) and DAPI (nuclei and PA, blue). (d) Western blot of PSD95 (postsynaptic marker), MAP-2 (maturation marker), and TUJ-1 (neuronal marker) of neuronal cells treated with Strv, BDNF peptide, BDNF PA, and BDNF protein during 2 weeks in vitro. (e) Bar graphs quantifying using densitometry analysis of MAP-2 maturation marker and PSD95 postsynaptic marker after treatments conditions shown in (d) (intensity values normalized to actin). $* \mathrm{P}<0.05, * * \mathrm{P}<0.01$ and $* * \mathrm{P}<0.001$, and $* * * * \mathrm{P}<0.0001$, LSD test (b) $(\mathrm{n}=60),(\mathrm{e})(\mathrm{n}=3)$. 
a
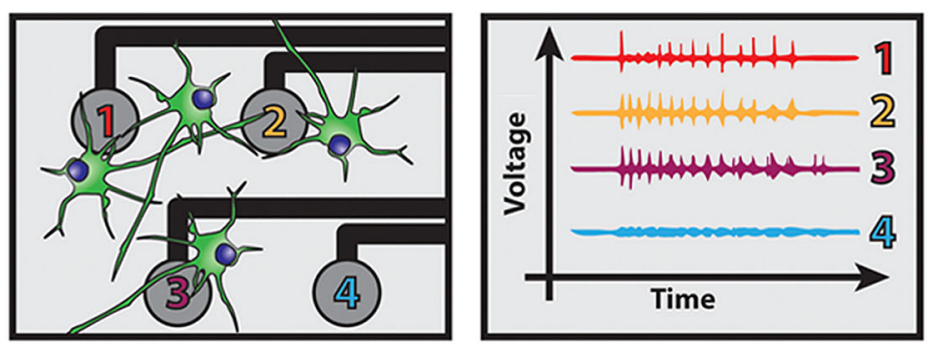

C

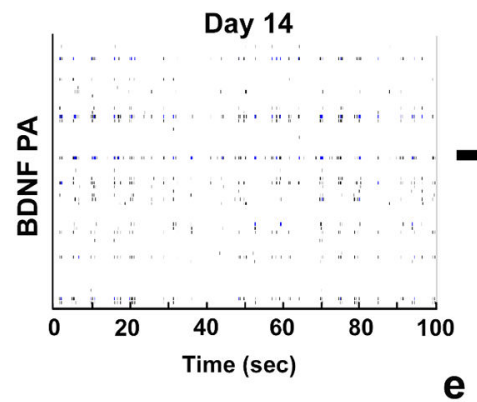

d

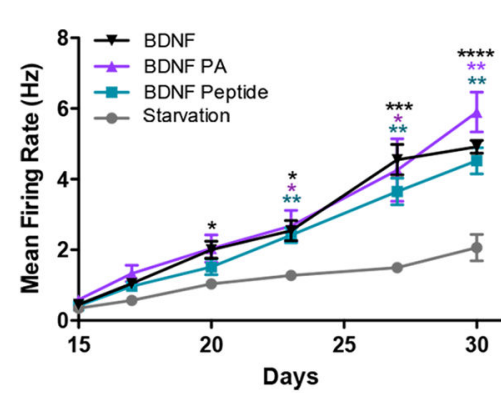

e

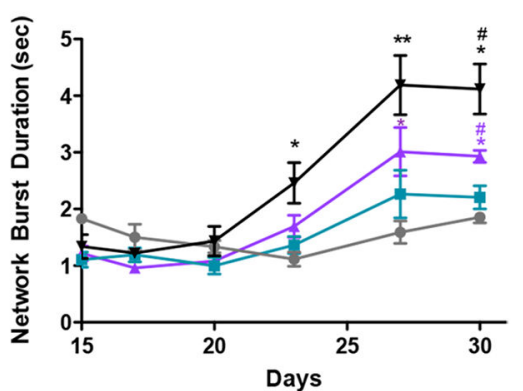

b

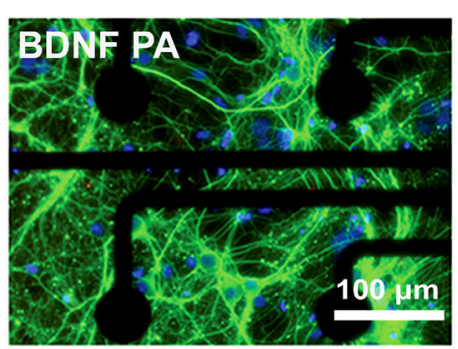

Day 30
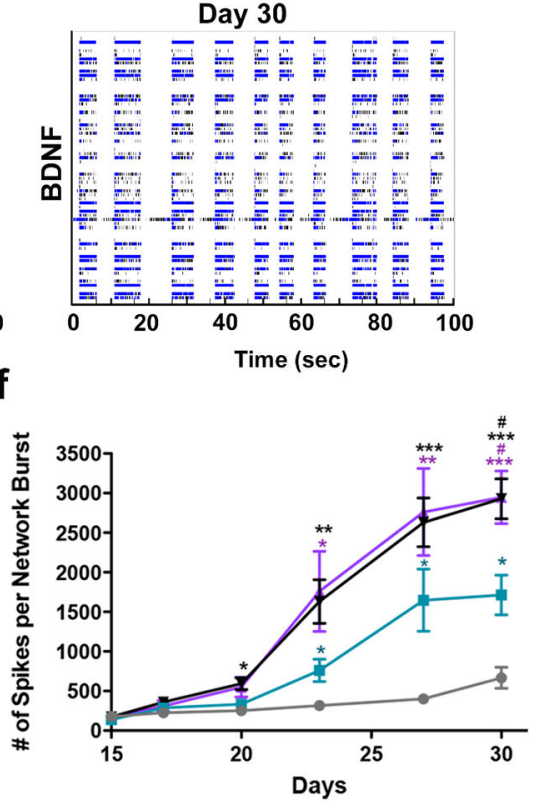

Figure 4. Multi-electrode array (MEA) recordings of neuronal cultures treated with BDNF PA. (a) Schematic of neurons plated on MEA plate (left) showing increased voltage activity from electrodes in contact with mature neurons (right). (b) Representative image of neurons cultured on MEA plate treated with BDNF PA for 30 days in vitro (cells immunostained with MAP-2, a marker of mature dendrites, green and DAPI, a stain for nuclei and PA, blue). (c) Representative raster plots showing electrical activity of culture at 14 and 30 days in vitro for wells treated with BDNF PA and BDNF protein. (d-f) Plots as a function of time of mean firing rate (d), network burst duration (e), and number of spikes per network burst (f) for cells treated with Strv, BDNF peptide, BDNF PA and BDNF protein during 2 weeks in vitro. $* \mathrm{P}<0.05, * * \mathrm{P}<0.01$ and $* * * \mathrm{P}<0.001$, and $* * * * \mathrm{P}<0.0001$ with respect to starvation media and \#P $<0.05$ with respect to BDNF peptide, LSD test ( $\mathrm{n}=8$ for BDNF PA and BDNF protein wells, and $n=4$ for Strv and BDNF peptide wells). 

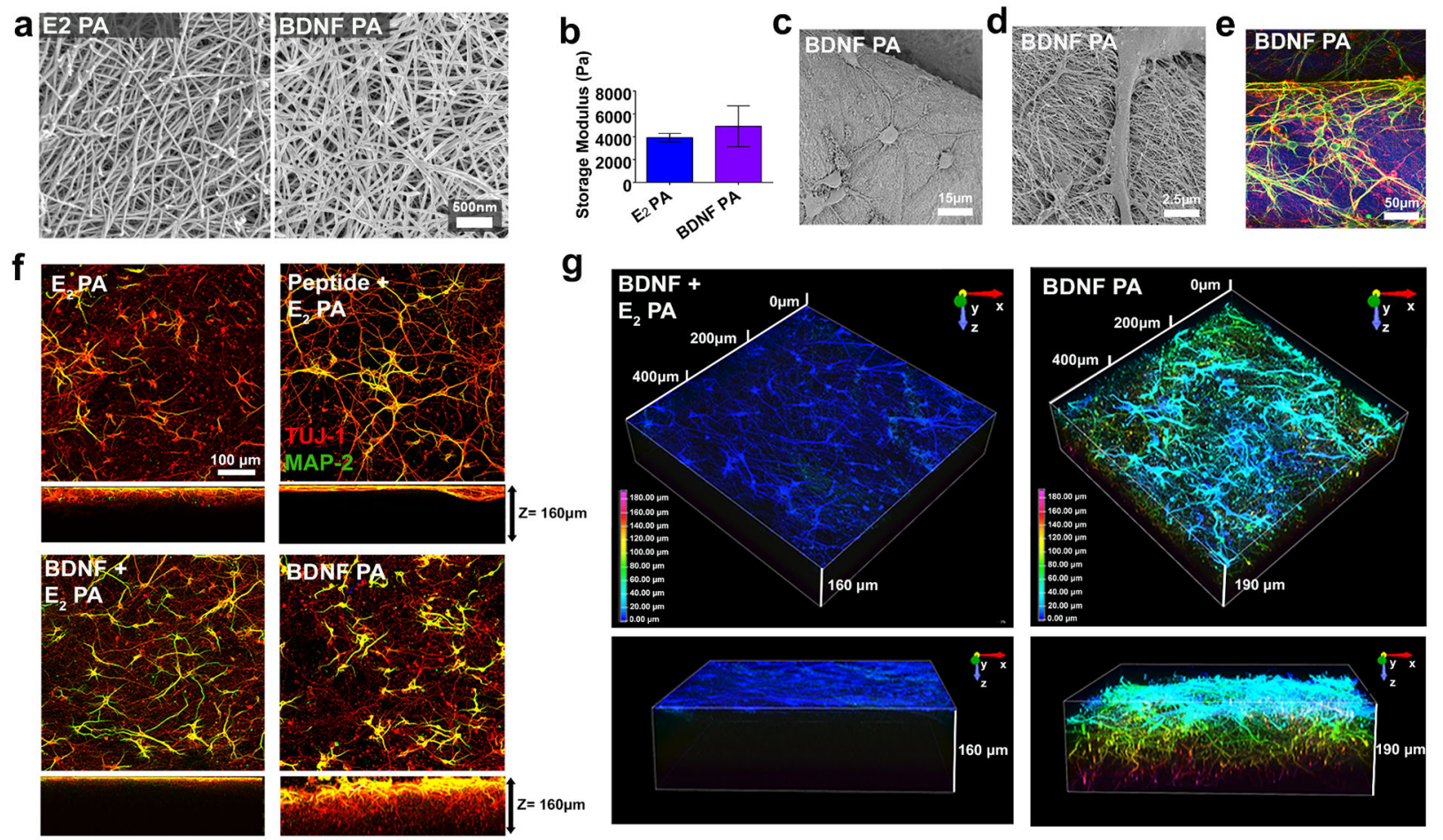

h
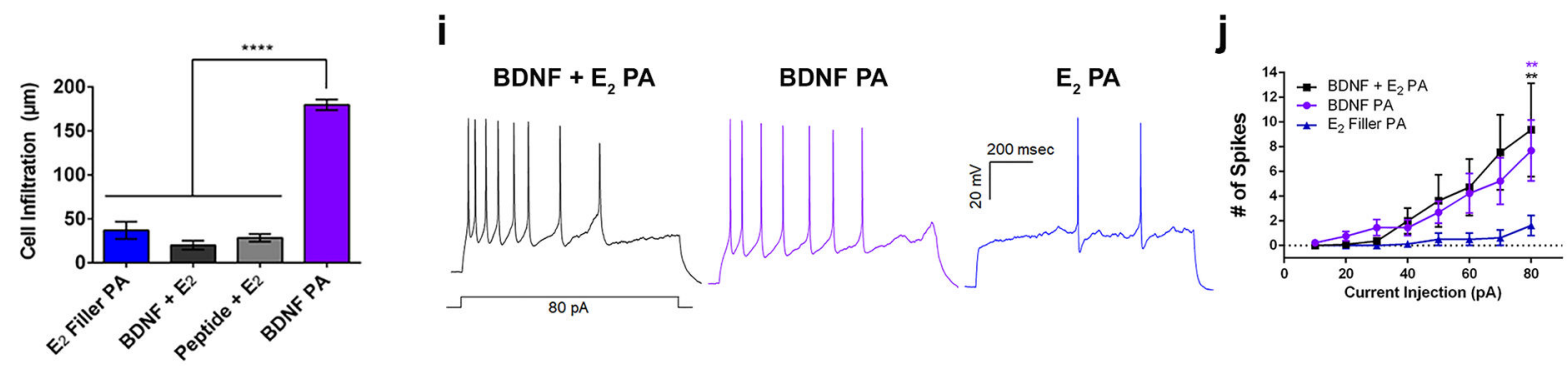

Figure 5. Infiltration and maturation of cortical neurons in BDNF PA scaffolds.

(a) SEM showing nanofibers in $E_{2}$ PA and BDNF PA gels. (b) Storage moduli of $E_{2}$ PA and BDNF PA. (c-d) Scanning electron micrograph and (e) confocal micrograph images showing cortical neurons seeded on top of 3D PA scaffolds for 1 week in vitro. (f) Confocal images showing top and side $(\mathrm{z}$-stack $=160 \mu \mathrm{m})$ view sections of cells cultured on PA gel scaffolds for 1 week in vitro (images show cells stained with MAP-2 (dendritic marker, green), and Tuj-1 (neuronal marker, red). (g) Depth-coded z-stack reconstructions showing cell infiltration after 1 week in vitro. (h) Quantification of cell infiltration depth in $\mathrm{E}_{2} \mathrm{PA}, \mathrm{BDNF}$ $+E_{2}$ PA, BDNF peptide $+E_{2}$ PA, and BDNF PA gels. (i) Representative traces of action potentials elicited by 1 second, 10pA current injection steps from 10-80pA recorded from neurons in BDNF $+\mathrm{E}_{2} \mathrm{PA}, \mathrm{BDNF} \mathrm{PA}$ and $\mathrm{E}_{2}$ PA gels, 1 week in vitro. (j) Plot of current injection versus number of spikes for conditions in (i). $* * \mathrm{P}<0.01$ and $* * * * \mathrm{P}<0.0001$. LSD test ( $b$ and $h$ ) and ANOVA followed by posthoc analysis was used for current clamp recordings $(\mathrm{j})$. 